\title{
Alasan Kurkumin Efektif Mempercepat Penyembuhan Luka di Kulit
}

\author{
Nasrul Wathoni \\ Fak ultas Farmasi, Univ ersitas Padjadjaran, Sumedang, Jawa Barat, Indonesia \\ Terbit online : $16 \mathrm{~J}$ uli 2016
}

\section{Abstrak :}

Kurkumin yang merupakan senyawa utama dari Kunyit (Curcuma longa) dan Temulawak (Curcuma Xanthoriza), baru-baru ini banyak penelitian terkait potensinya yang mampu mempercepat proses penyembuhan luka di kulit baik luka akut maupun kronis. Secara natural, ada 4 tahapan proses penyembuhan luka dimana setiap tahapannya saling tumpang tindih. Tahapan itu adalah hemostatis, inflamasi/peradangan, proliferasi, dan remodeling. Banyak penelitian pra-klinis telah menunjukkan bahwa kurkumin mampu bekerja pada fase inflamasi, proliferasi dan remodeling dari proses penyembuhan luka sehingga mampu mengurangi waktu yang dibutuhkan untuk penyembuhan luka.

Keyword: kurkumin, luka, temulawak, kunyit

\section{Pendahuluan}

Curcumin/kurkumin yang merupakan senyawa utama dari Kunyit (Curcuma longa) dan Temulawak (Curcuma Xanthoriza), baru-banu ini banyak penelitian terkait potensinya yang mampu mempercepat proses penyembuhan luka di kulit baik luka akut maupun kronis.

Semua orang pasti pemah mengalami luka di kulit baik itu terjatuh maupun karena kecelakaan yang tidak terduga lainnya. Waktu penyembuhan luka tergantung dari berbagai faktor, termasuk kondisi dari pasien. Pasien yang memiliki riwayat diabetes berpotensi mengalami luka kronis atau proses penyembuhannya terganggu secara natural .

Pada luka diabetes, jumlah neutrofil pada tempat luka meningkat pesat sebagai akibat adanya reaksi radikal bebas oksigen yang tinggi, selain itu mediator peradangan/inflamasi meningkat menyebabkan timbul peradangan hebat di kulit. Matrik ekstraselular terdegradasi karena aktivitas degradasi dari growth factor yang menyebabkan sel tidak mampu untuk berproliferasi sehingga aktivitas penyembuhan luka terhambat bahkan rentan ditumbuhi bakteri.

Kunyit dan temulawak merupakan tanaman obat yang melimpah di Indonesia dan ternyata kurkumin memiliki prospek cerah sebagai senyawa yang mampu memercepat pengobatan luka.

\section{Apa itu kurkumin?}

Kurkumin (diferuloylmethane) adalah kurkuminoid utama dalam kunyit dan temulawak yang bertanggung jawab untuk warna kuning. Kurkumin telah terbukti memiliki aktivitas antiinflamasi, anti-oksidan, anti-karsinogenik, anti-mutagenik, anti-koagulan dan efek anti-infeksi. Selain itu, curcumin juga telah terbukti meningkatkan kemampuan penyembuhkan luka secara signifikan. 


\section{Mekanisme kurkumin dalam membantu menyembuhkan luka}

Secara natural, ada 4 tahapan proses penyembuhan luka dimana setiap tahapannya saling tumpang tindih. Tahapan itu adalah hemostatis, inflamasi/peradangan, proliferasi, dan remodeling.

Tahap hemostasis dimulai segera setelah terjadinya luka, melalui agregasi platelet dan pembentukan bekuan fibrin. Kemudian, tahap inflamasi dapat didentifikasi dengan adanya neutrofil untuk penghilangan kotoran luka serta makrofag yang melepaskan sitokin pada lokasi luka. Pada tahap proliferatif, fibroblas menembus luka dan mendeposit matriks ekstraselular baru untuk memulai proses re-epitelisasi. Akhirnya, sintesis kolagen dan myofibroblasts memfasilitasi proses remodeling jaringan lebih lanjut. Semua tahapan harus terjadi dalam urutan yang benar dan jangka waktu yang tepat untuk memastikan kesembuhan secara total

Efek dari kurkumin pada luka pada setiap fase penyembuhan terangkum dibawah ini

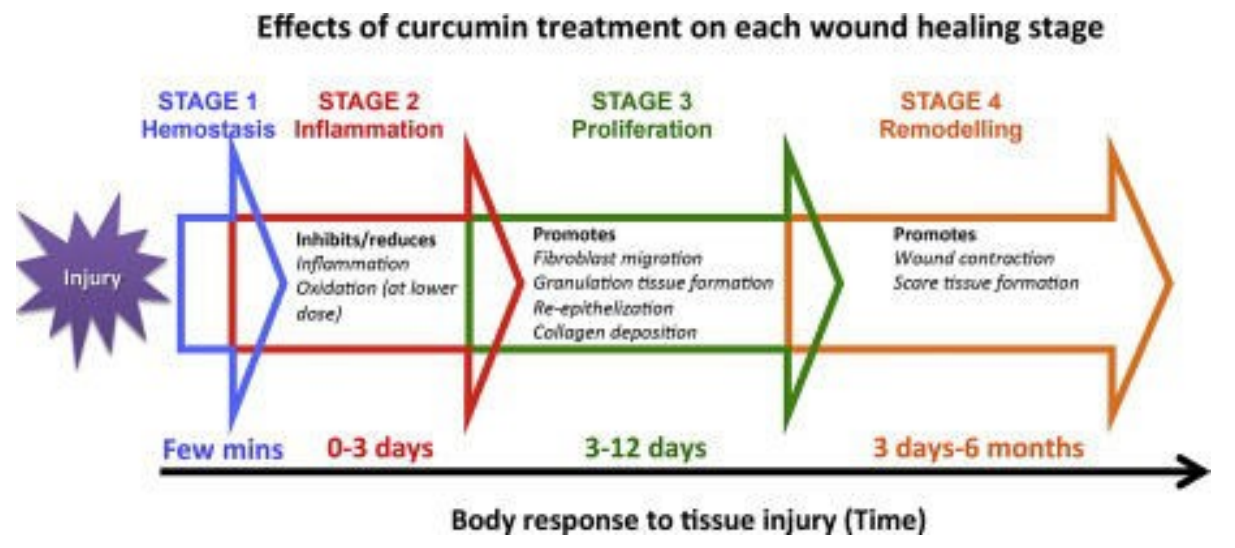

Gambar 1. Efek dari kurkumin pada penyembuhan luka (pic: Akbik et al, 2014)

Tahap Inflamasi

-Menghambat transkripsi aktivitas faktor NF (K) B, mengurangi produksi sitokin TNF-a dan IL-1 sehingga mampu mengurangi peradangan

- Menurunkan radikal bebas ROS (pada dosis rendah dari kurkumin)

- Meningkatkan pembentukan ROS (pada dosis lebih tinggi dari kurkumin)

- Meningkatkan atau menurunkan produksi enzim anti-oksidan (tergantung dosis)

Tahap Proliferasi

-Meningkatkan migrasi fibroblast, pembentukan jaringan granulasi, deposisi kolagen, dan secara umum re-epitelisasi

-Menjadi apoptosis pada fase awal penyembuhan luka, sehingga menghilangkan sel-sel inflamasi yang tidak diinginkan di tempat luka

Remodeling

-Meningkatkan kontraksi luka dengan meningkatkan produksi TGF- $\beta$ dan karena itu mampu meningkatkan proliferasi fibroblast 
Banyak penelitian pra-klinis telah menunjukkan bahwa kurkumin mampu bekerja pada fase inflamasi, proliferasi dan remodeling dari proses penyembuhan luka sehingga mampu mengurangi waktu yang dibutuhkan untuk penyembuhan luka.

Sayangnya, senyawa kurkumin dibatasi oleh sifat bioavailabilitas yang rendah, metabolisme yang cepat, kelarutan rendah dan sensitivitas terhadap cahaya. Untuk meminimalkan efek tersebut dan untuk dapat menggunakan kurkumin secara maksimal, maka dibutuhkan formulasi baru seperti bentuk nanopartikel atau kompleksasi dengan siklodekstrin yang harus dieksplorasi.

Selain itu, hingga saat ini penelitian belum sampai ke tahap pengujian klinis.

Daftar pustaka :

Dania Akbik, Maliheh Ghadiri, Wojciech Chrzanowski, Ramin Rohanizadeh. Curcuminas a wound healing agent, Life Sciences, Volume 116, Issue 1, 22 October 2014, Pages 1-7 